\title{
Yield and Soluble Solids Content of Winter-grown Spinach in Unheated High Tunnels in New England
}

\author{
Kaitlyn M. Orde and Connor Eaton \\ Department of Biological Sciences, University of New Hampshire, 38 \\ Academic Way, Durham, NH 03824

\section{Rebecca G. Sideman ${ }^{1}$ \\ Department of Agriculture, Nutrition and Food Systems, University of New Hampshire, 38 Academic Way, Durham, NH 03824}

Additional index words. season extension, high tunnel, overwintering, Spinacia oleracea, spinach, New England, soluble solids content

\begin{abstract}
Fall planting of spinach (Spinacia oleracea L.) into high tunnels for harvest from late fall through early spring is widely practiced in the northeastern United States, but replicated studies focusing on this production system are lacking. The objectives of our study were to understand the effect of fall planting date (PD) and cultivar on yield and soluble solids content (SSC) of spinach. Three cultivars (Regiment, Space, and Tyee) were transplanted in unheated high tunnels in Durham, NH, in 2014-15 (Year 1) and 2015-16 (Year 2) at six different fall dates: 20 Sept., 30 Sept., 9 Oct., 19 Oct., 30 Oct., and 9 Nov. Five additional cultivars (Carmel, Corvair, Gazelle, Emperor, and Renegade) were included at the third date (9 Oct.) to compare yield and SSC among cultivars during winter months. A randomized complete block design with four replications was used for all experiments. Year and fall transplant date had a significant effect on total yield. Total yield of Year 2 was nearly double that of Year 1 for all PDs and cultivars. In both years, total yield decreased with later planting, such that yield from the 20 Sept. date was greater than a minimum of three of five subsequent PDs, depending on year. Total yield in spring (January through April) did not differ among the first four PDs in Year 1 or among any dates in Year 2, suggesting that a wide range of PDs will work well for those primarily interested in spring harvests. Combined analyses of the data from both years showed no significant differences in total yield among the eight cultivars planted only on 9 Oct. However, of the three cultivars grown at all PDs, Regiment produced significantly higher yields than Tyee. Harvest date, cultivar, and harvest date $\times$ cultivar affected leaf and petiole sap SSC in both years. SSC was most strongly negatively correlated with air and soil temperatures at a 10-day interval in Year $1\left(R^{2}=0.61\right.$ and 0.64 , respectively) and a 7-day interval in Year $2\left(R^{2}=0.78\right.$ and 0.69 , respectively). 'Gazelle' and 'Emperor' contained among the highest SSC in both years. Our work demonstrates total yield is highly dependent on fall PD and the growing conditions of a given year.
\end{abstract}

In the New England region, high tunnels are typically used to lengthen the growing season for warm-season crops such as tomato (Solanum lycopersicum L.) (Carey et al., 2009; Fitzgerald and Hutton, 2012; Hunter et al., 2012; Knewtson et al., 2010; Lamont, 2009; O'Connell et al., 2012). However, 38\%

Received for publication 6 Feb. 2018. Accepted for publication 23 Mar. 2018.

Partial funding was provided by the New Hampshire Vegetable and Berry Growers' Association and the New Hampshire Agricultural Experiment Station. This is Scientific Contribution Number 2732. This work was supported by the USDA National Institute of Food and Agriculture Hatch Project NH00635.

We thank farm, greenhouse, and technical staff at the University of New Hampshire. We also thank Ryan Dickson and Mark Hutton for providing thoughtful reviews of our manuscript.

${ }^{1}$ Corresponding author. E-mail: becky.sideman@ unh.edu. of Maine growers surveyed by Fitzgerald and Hutton (2012) reported using high tunnels for crop production during the winter months and a 2016 survey of 110 high tunnel producers in northern New England revealed that $41 \%$ used their tunnels for production of greens during the winter months (R.G. Sideman, unpublished data). Although there are few reports of this production practice in the scientific literature, fall planting of coldtolerant vegetable crops in unheated high tunnels for harvest and sales throughout the fall and winter months is increasingly commonplace in the Northeast. Thus, maximizing tunnel production during fall, winter, and early spring, when consumer demand for local produce is high (Carey et al., 2009; Wien and Pritts, 2009), can assist growers in obtaining premium pricing (Bjelić and Moravčević, 2006; Gent, 1991) and maintaining their customer base during the off-season.

Spinach (S. oleracea L.) is one of the most popular crops for winter high tunnel cultivation
(Carey et al., 2009; Fitzgerald and Hutton, 2012; Knewtson et al., 2010; Lamont, 2009; Lamont et al., 2003). Although the optimal temperature range for spinach growth is 12 to $15{ }^{\circ} \mathrm{C}$ (Bjelić and Moravčević, 2006), spinach has a high tolerance to chilling damage (Guy and Haskell, 1987; Nobel, 1974; Tamura, 2002) and has the ability to gain freezing tolerance through acclimation to low temperatures (Fennell and Li, 1985). Fennell and Li (1985) showed that the $\mathrm{LT}_{50}$ of four spinach cultivars was about $-6.5{ }^{\circ} \mathrm{C}\left(\mathrm{LT}_{50}\right)$ before acclimation but decreased to -12 to $-17{ }^{\circ} \mathrm{C}$ $\left(\mathrm{LT}_{50}\right)$ (depending on cultivar) after 2 weeks of low temperature acclimation.

Regional producers report winter-grown spinach to be sweeter than summer-grown spinach (Blomgren and Frisch, 2007), and controlled experiments show that SSC and soluble sugar levels in leaves increase with exposure to low temperatures (Gent, 2016; Guy et al., 1992; Ito et al., 2013, 2015; Proietti et al., 2009). In the temperature range of 16.1 to $23.5{ }^{\circ} \mathrm{C}$, Gent (2016) showed that sugar content within petioles increased when temperatures dropped below $20{ }^{\circ} \mathrm{C}$ and Proietti et al. (2009) report that after $7 \mathrm{~d}$ at $10^{\circ} \mathrm{C}$, soluble sugar content (glucose, fructose, and sucrose) of spinach leaves increased by $51 \%$. Furthermore, Ito et al. $(2013,2015)$ demonstrated that SSC increases faster with exposure to colder temperatures and showed that levels significantly increased in only $4 \mathrm{~d}$ of root exposure to $4{ }^{\circ} \mathrm{C}$, vs. $7 \mathrm{~d}$ of exposure to $14{ }^{\circ} \mathrm{C}$. In addition, Guy et al. (1992) report that free sugar content (glucose, fructose, and sucrose) increased by 10 to 20 -fold after $14 \mathrm{~d}$ at $5{ }^{\circ} \mathrm{C}$ and that sucrose phosphate synthase, the primary biosynthetic enzyme of sucrose, was more abundant at $5{ }^{\circ} \mathrm{C}$ than $10{ }^{\circ} \mathrm{C}$.

A primary driver in such increases in SSC is osmotic adjustment. Under cold conditions, plants enter a state of low temperature-induced dehydration and through the synthesis of soluble solids, osmotically adjust to ensure turgor pressure and normal plant processes are maintained (Taiz and Zeiger, 2002). Sugars, especially, are a primary compatible solute used for the protection of protein structure and function (Bohnert and Shen, 1999) and chloroplast membranes during freezing conditions (Levitt, 1980). Thus, the production of sugars and other compatible solutes have a cryoprotective effect on plants (Guy et al., 1992; Levitt, 1980; Taiz and Zeiger, 2002).

Studies of off-season spinach production in high tunnels are limited and are geographically restricted to the midwestern, western, and Pacific northwestern United States (Borrelli et al., 2013; Ernst et al., 2012; Knewtson, 2008). Other studies have focused on the practice of direct seeding before hard frost for early spring production (Bjelić and Moravčević, 2006), a strategy that does not address winter-long production. We are not aware of any published research on the effects of PD, cultivar, and temperature on 
yield and SSC of spinach grown in this production system in the northeastern United States.

Our objectives in this study were to understand the effect of fall PD and cultivar on yield and SSC of spinach leaves. Planting dates and cultivars with greater yields may provide added revenue for producers, and practices that increase SSC and sweetness will likely add to the consumer perception of exceptional eating quality.

\section{Methods}

\section{Location}

Both experiments were conducted at the University of New Hampshire Woodman Horticultural Research Farm in Durham, $\mathrm{NH}$ (lat. $43^{\circ} 15^{\prime} \mathrm{N}$, long. $70^{\circ} 94^{\prime} \mathrm{W}$ ), over two seasons: 2014-15 (Year 1) and 201516 (Year 2). The site is located in U.S. Department of Agriculture (USDA) hardiness zone $5 \mathrm{~B}$ and has an average annual extreme minimum temperature of -26.1 to $-23.3^{\circ} \mathrm{C}$ (USDA, 2012) and fall and spring frost dates $\left(0{ }^{\circ} \mathrm{C}\right)$ of 24 Sept. and 13 May, respectively $(50 \%$ probability of occurring earlier and later) (NOAA, 2018).

\section{Cultivars \& experimental design}

Three cultivars, Regiment, Space, and Tyee, were transplanted into high tunnels at six different fall dates as part of a $P D$ experiment (PD Exp.): 20 Sept. (A), 30 Sept. (B), 9 Oct. (C), 19 Oct. (D), 30 Oct. (E), and 9 Nov. (F), henceforth referred to as PD A through $\mathrm{F}$ (Table 1). On PD C, five additional cultivars were included for a cultivar experiment (Cultivar Exp.): Carmel, Corvair, Gazelle, Emperor and Renegade. The Cultivar Exp. focused on measuring SSC in addition to yield. The eight cultivars listed were selected to represent all leaf types (smooth to savoy) and varying resistance to downy mildew (Table 2), a new but serious risk to spinach production in the Northeast (McGrath, 2017). A randomized complete block design with four complete blocks was used in both years. Planting date served as the main plot and cultivar as the subplot. In Year 1, experimental units measured $1.0 \mathrm{~m}$ wide $x$ $0.64 \mathrm{~m}$ long and consisted of 25 plants. In Year 2, experimental units measured $1.2 \mathrm{~m}$ wide and $0.5 \mathrm{~m}$ long and consisted of 24 plants.

\section{Cultural practices}

The high tunnels used for the experiments were on adjacent fields (16 $\mathrm{m}$ apart). In Year 1, plants were grown in an $18.3 \times 9.1-\mathrm{m}$ stationary high tunnel (Ledgewood Farms, Moultonborough, NH). The tunnel was covered with a single layer of 6-mil, 4-year ultraviolet-treated polyethylene plastic with polycarbonate end walls and was equipped with two electric louver vents and exhaust fans set to vent at $21.1^{\circ} \mathrm{C}$. Rollup sides were manually adjusted to maintain an internal temperature below $21.1^{\circ} \mathrm{C}$. In Year 2, crop rotation on the research farm required the experiment be conducted in a $14.6 \times 9.1-\mathrm{m}$ moveable high tunnel (Rolling Thunder; Rimol Greenhouse Systems, Inc., Hooksett, $\mathrm{NH})$. The tunnel was covered in an inflated double layer of 6-mil, 4-year plastic and also had polycarbonate end walls. Electric gable shutters and automated rollup sides maintained an internal temperature below $21.1^{\circ} \mathrm{C}$. High tunnels were not equipped with heating systems and did not receive supplemental heating throughout experiments.

Before the onset of the spinach experiment in Year 1, the high tunnel was amended with $1343 \mathrm{~kg} \cdot \mathrm{ha}^{-1}$ 5N-1.3P-3.3K (North Country Organics, Bradford, VT) and used to grow tomatoes. An early-fall soil test

showed that the site was very high in phosphorus and potassium, and therefore, no additional fertility was added before the start of the spinach experiment. In Year 2, based on soil test results and recommendations for commercial spinach production (Dicklow and McKeag, 2016), soil was amended before bed formation with $506 \mathrm{~kg} \cdot \mathrm{ha}^{-1}$ of both $13 \mathrm{~N}-$ $0 \mathrm{P}-0 \mathrm{~K}$ (Nature Safe, Irving, $\mathrm{TX}$ ) and $0 \mathrm{~N}-$ $0 \mathrm{P}-18.3 \mathrm{~K}$.

In both years, four raised beds measuring the length of the high tunnels were formed. Beds measured $15 \mathrm{~cm}$ high and were $1.2 \mathrm{~m}$ (Year 1) and $1.4 \mathrm{~m}$ (Year 2) wide. Aisles between beds were $0.9 \mathrm{~m}$ (Year 1) and $0.7 \mathrm{~m}$

Table 1. Seeding dates, planting dates (PDs), and spinach cultivars included in high tunnel experiments in Durham, NH, in 2014-15 (Year 1) and 2015-16 (Year 2).

\begin{tabular}{lrrl}
\hline Planting & Seeding date & PD & \multicolumn{1}{c}{ Cultivars } \\
\hline A & 29 Aug. & 20 Sept. & Regiment, Space, and Tyee \\
B & 8 Sept. & 30 Sept. & Regiment, Space, and Tyee \\
C & 18 Sept. & 9 Oct. & Regiment, Space, Tyee, Carmel, Corvair, \\
& & & Gazelle, Emperor, and Renegade \\
D & 29 Sept. & 19 Oct. & Regiment, Space, and Tyee \\
E & 9 Oct. & 30 Oct. & Regiment, Space, and Tyee \\
F & 19 Oct. & 9 Nov. & Regiment, Space, and Tyee \\
\hline
\end{tabular}

Table 2. Seed source and descriptions of the eight spinach cultivars included in high tunnel experiments in Durham, NH, in 2014-15 (Year 1) and 2015-16 (Year 2).

\begin{tabular}{|c|c|c|c|c|}
\hline Cultivar & Source $^{\mathrm{z}}$ & Leaf type & DM resistance $^{y}$ & Attributes \\
\hline Regiment & HM & Lightly savoy & Races 1-7 & Slightly upright growth habit \\
\hline Space & JSS & $\begin{array}{l}\text { Smooth to } \\
\text { lightly savoy }\end{array}$ & Races $1-3,5,6,8,11,12$ & Slightly upright growth habit \\
\hline Tyee & JSS & Savoy & Races 1-3 & $\begin{array}{l}\text { Slightly upright growth habit } \\
\text { leaves tended to curl and } \\
\text { become brittle }\end{array}$ \\
\hline Carmel & JSS & Semi-savoy & Races $1-11,13$ & $\begin{array}{l}\text { Upright growth habit, bushy, } \\
\text { and small uniform leaves }\end{array}$ \\
\hline Corvair & HM & Smooth & Races $1-11,13$ & Slightly upright growth habit \\
\hline Gazelle & JSS & Smooth & Races 1-13 & Upright growth habit \\
\hline Emperor & JSS & Semi-savoy & Races $1-10$ & Upright growth habit \\
\hline Renegade & JSS & Smooth & Races 1-7 & Prostrate growth habit \\
\hline
\end{tabular}

${ }^{\mathrm{z}}$ Seed sources are JSS = Johnny's Selected Seeds (Albion, ME), and HM = High Mowing Organic Seeds (Wolcott, VT).

${ }^{\mathrm{y}} \mathrm{DM}=$ Downy mildew resistance information obtained from commercial seed suppliers.

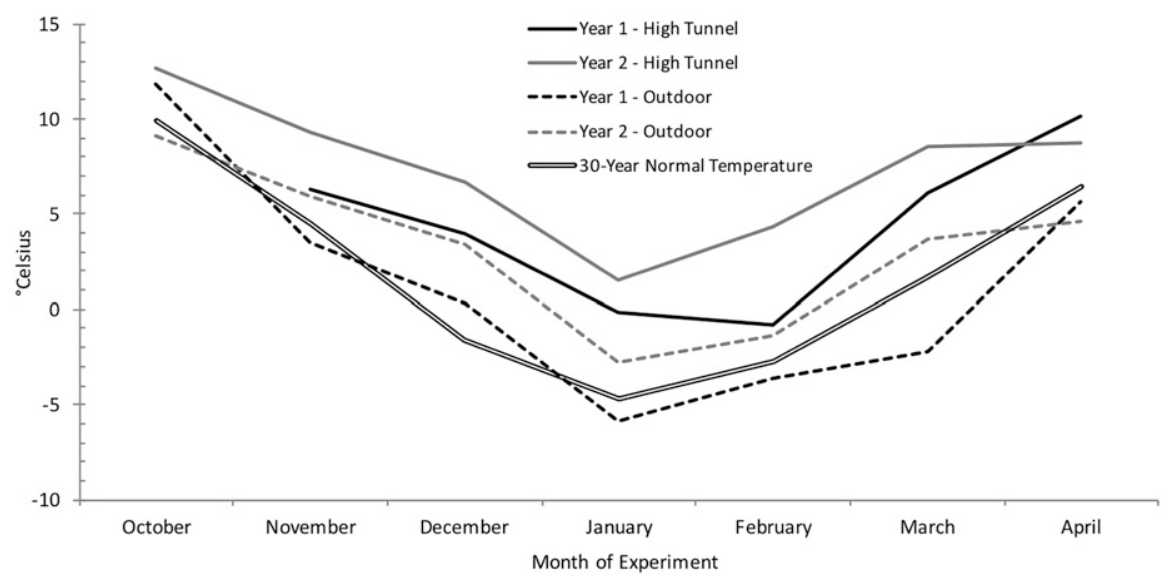

Fig. 1. Monthly mean high tunnel and outdoor temperatures $\left({ }^{\circ} \mathrm{C}\right)$ for Durham, NH, in 2014-15 (Year 1) and 2015-16 (Year 2). Normal refers to the 30-year (1981-2010) monthly air temperature average reported for Durham, NH, by the U.S. Department of Commerce (2010). High tunnel temperature measurements were taken at plant height under a single layer of Agribon+ AG-19 rowcover from 6 Nov. 2014 (Year 1) and 14 Dec. 2015 (Year 2) though mid-March. October and Nov. 2014 outdoor air temperatures are reported by the University of New Hampshire Weather Station (2016). April average temperature is for the first half of April (1-15 Apr., inclusive). 
(Year 2), and a minimum of a $0.7 \mathrm{~m}$ buffer existed between beds and side and end walls. Bed width was modified in Year 2 to ensure comparable plant numbers per replication because the tunnel was shorter in length than the tunnel used in Year 1. Plant spacing was $20.3 \mathrm{~cm}$ by $12.7 \mathrm{~cm}$, for a plant density of $38.7 \mathrm{plants} / \mathrm{m}^{2}$, to align with the plant spacing reported by growers in the region.

Plants were started by seed in 128-cell trays of Pro-Mix BX soilless media (Pro-Mix, Quakertown, PA) and transplanted into the high tunnel 3 weeks after seeding. In Year 1, the plants were germinated in a climatecontrolled greenhouse. In Year 2, temperatures in late August consistently exceeded $27{ }^{\circ} \mathrm{C}$, hindering germination of the first seeding. To ensure adequate plant quantities for the study, subsequent seeds were germinated in an incubator (model I-36VL; Percival Scientific, Inc., Perry, IA) at $15^{\circ} \mathrm{C}$ with a 12-h light/dark cycle and removed from the chamber after 1 week. Following germination, cells were thinned to one plant and irrigated daily with a fertilizer nutrient solution at $0.0107 \mathrm{~mol} \cdot \mathrm{L}^{-1}$ nitrogen $(15 \mathrm{~N}-1.7 \mathrm{P}-$ 12.5K; Jack's Professional Poinsettia FeED; JR Peters, Inc., Allentown, PA), which was mixed and applied with tap water until the plants were transplanted into the high tunnel. Transplants, as opposed to direct-seeded plants, were used to ensure consistent plant quantities and because this is a typical practice among commercial growers in the region, who have reported challenges with seed germination within high tunnels in the earlyfall months. In addition, this method allows the high tunnel to be used for existing crops throughout the spinach germination period. Following transplant, seedlings were irrigated as needed using overhead watering. The "feel method" was used to determine soil water content, and plants were irrigated when soil formed a weak ball and was estimated to be $60 \%$ deficit in water (Martin, 2009).

When temperatures began to consistently drop below freezing, a single layer of Agribon+ AG-19 rowcover (Polymer Group, Inc., San Luis Potosí, México) was suspended $0.9 \mathrm{~m}$ above the crop as is typically practiced by regional spinach producers (Blomgren and Frisch, 2007) and to reduce mortality in the winter production of other vegetable crops (Martin and Sideman, 2012). Rowcover was applied on 6 Nov. 2014 and 14 Dec. 2015 and was left in place throughout the winter except for temporary removal during harvest. It was permanently removed in the spring of both years once nighttime outdoor minimum temperatures were regularly above $0{ }^{\circ} \mathrm{C}$ (mid-March).

\section{Pest control}

In Year 1, there was no sufficient pest pressure to warrant any control measures. In Year 2, cutworms (Noctuidae spp.) were controlled with two applications of Bacillus thuringiensis (Dipel PRO DF; Valent BioSciences Corporation, Libertyville, IL) on 6 Nov. and 10 Dec. 2015. High aphid populations were managed with the release of predatory lacewing larvae (Chrysoperla sp.;
Biobest Belbium NV, Oevel, Belgium) on 20 Oct. and ladybeetles (Hippodamia convergens; A-1 Unique Insect Control, Citrus Heights, CA) on 25 Feb., 4 Mar., 8 Mar., and 1 Apr. 2016. Ladybeetles were not available from the supplier on 20 Nov. and lacewing larvae, which cannot fly and were likely to remain inside the high tunnel when sidewalls were raised, were used instead. The final release of ladybeetles was also deployed during a time of year when ventilation through the sidewalls was enabled, but they were released late afternoon when temperatures were low enough so the sidewalls would contain the predators for at least $12 \mathrm{~h}$.

\section{Data collection}

Yield. Harvests were conducted as needed every 1-3 weeks from October through April, with the exception of January and February, when they occurred once per month. All plants were harvested at each harvest date, so long as they contained marketable leaves for salad mix, defined as $10-15 \mathrm{~cm}$ from petiole base to the tip of the leaf apex. Leaves (including petioles) were removed by pinching the

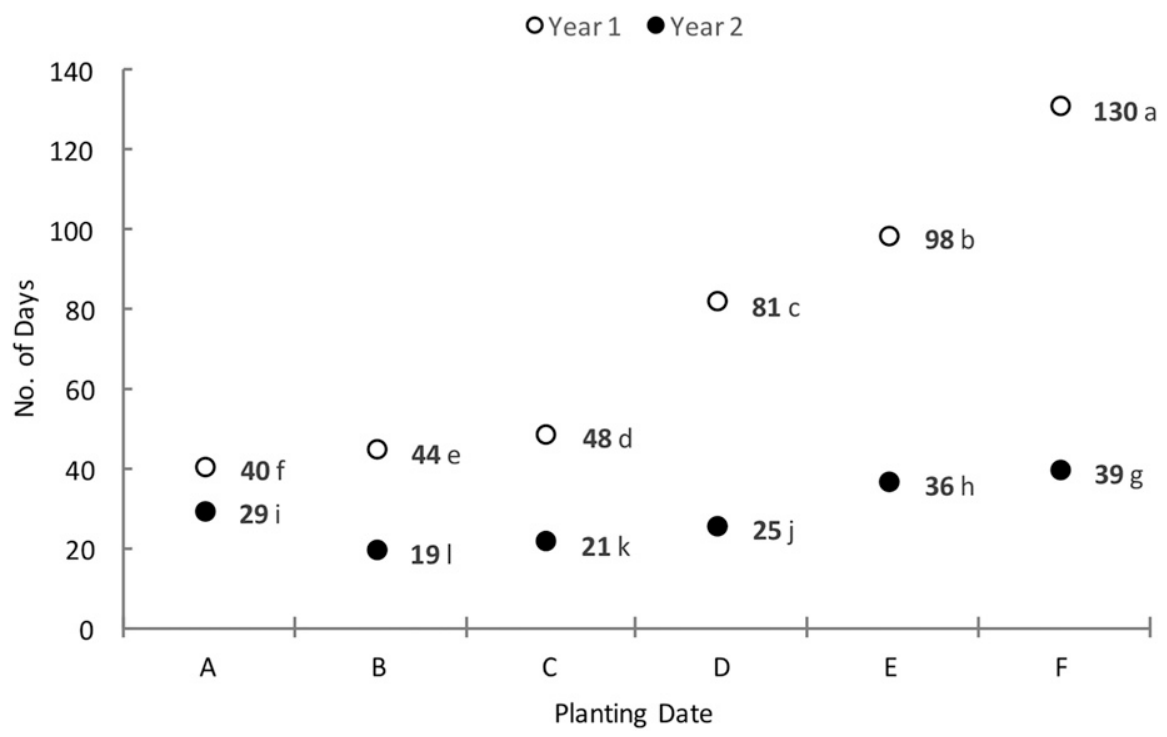

Fig. 2. Number of days from transplant of 3-week-old seedlings until first harvest for spinach planted at six fall dates into unheated high tunnels in Durham, NH, in 2014-15 (Year 1) and 2015-16 (Year 2). Letters represent planting date (PD), where $A=20$ Sept., $B=30$ Sept., $C=9$ Oct., $D=19$ Oct., $E=30$ Oct., and $\mathrm{F}=9$ Nov. Values sharing letters are not significantly different $(P \leq 0.05$, Tukey's honestly significant difference) $(n=12$, except for PD C, where $n=32)$.

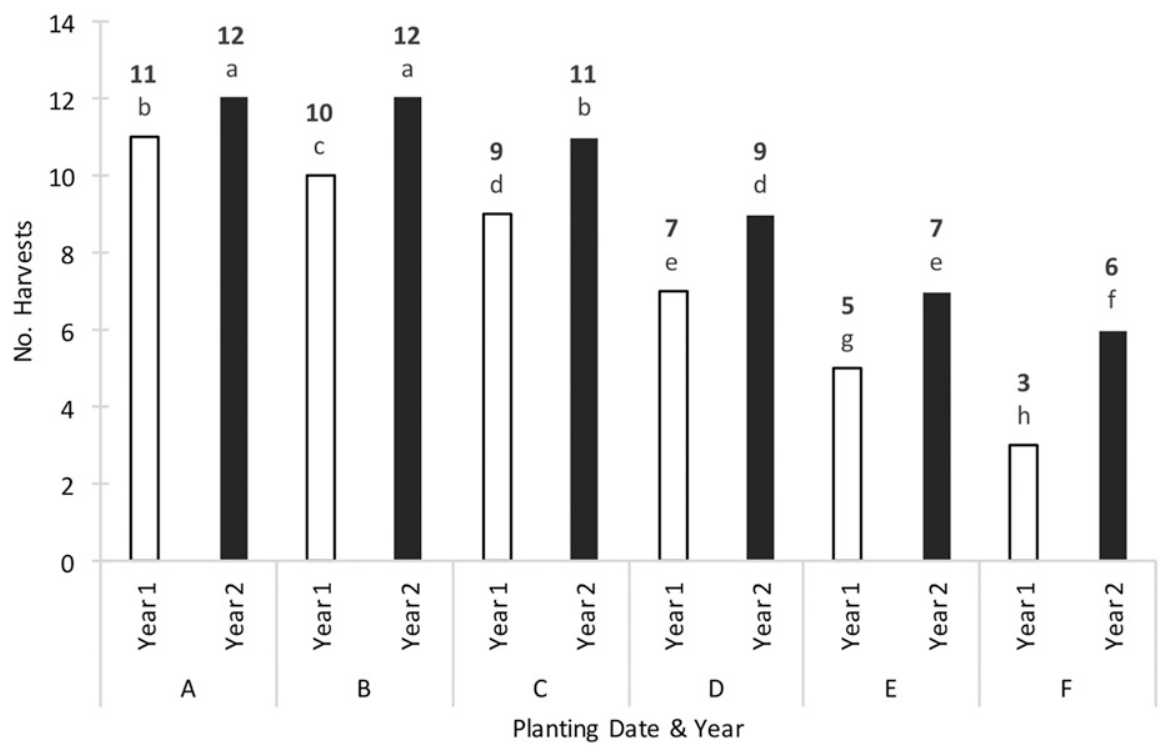

Fig. 3. Number of harvests obtained from spinach planted at six fall dates into unheated high tunnels in Durham, NH, in 2014-15 (Year 1) and 2015-16 (Year 2). Letters represent planting date (PD), where $\mathrm{A}=20$ Sept., $\mathrm{B}=30$ Sept., $\mathrm{C}=9$ Oct., $\mathrm{D}=19$ Oct., $\mathrm{E}=30$ Oct., and $\mathrm{F}=9$ Nov. Values sharing letters are not significantly different $(P \leq 0.05$, Tukey's honestly significant difference) $(n=12$, except for PD C, where $n=32$ ). 
base of the petiole and marketable weights were recorded by experimental unit. As opposed to destructive harvesting, this method promoted continuous production from one plant, and plants were repeatedly harvested throughout the duration of the experiment. To obtain per plant yield, marketable weights were divided by the number of living plants within experimental units, which was verified at every harvest.

Table 3. Year, cultivar, and planting date (PD) effects on total yield of spinach grown in unheated high tunnels in 2014-15 (Year 1) and 2015-16 (Year 2) in Durham, NH.

\begin{tabular}{|c|c|c|}
\hline \multicolumn{3}{|c|}{ Yield (g/plant) } \\
\hline Year & & \\
\hline Year 1 & \multicolumn{2}{|c|}{$60.6 \mathrm{~b}^{\mathrm{z}}$} \\
\hline Year 2 & \multicolumn{2}{|c|}{$112.7 \mathrm{a}$} \\
\hline \multicolumn{3}{|l|}{ Cultivar } \\
\hline Regiment & \multicolumn{2}{|c|}{$91.8 \mathrm{a}$} \\
\hline Space & \multicolumn{2}{|c|}{$86.8 \mathrm{ab}$} \\
\hline Tyee & \multicolumn{2}{|c|}{$81.4 \mathrm{~b}$} \\
\hline PD & Year 1 & Year 2 \\
\hline A (20 Sept.) & $83.8 \mathrm{a}$ & $165.3 \mathrm{a}$ \\
\hline B (30 Sept.) & $70.7 \mathrm{a}$ & $148.5 \mathrm{a}$ \\
\hline C (9 Oct.) & $78.6 \mathrm{a}$ & $117.6 \mathrm{~b}$ \\
\hline D (19 Oct.) & $51.7 \mathrm{~b}$ & $101.0 \mathrm{~b}$ \\
\hline E (30 Oct.) & $42.2 \mathrm{bc}$ & $75.9 \mathrm{c}$ \\
\hline F (9 Nov.) & $36.8 \mathrm{c}$ & $67.9 \mathrm{c}$ \\
\hline \multicolumn{3}{|l|}{ Significance $^{\mathrm{y}}$} \\
\hline Year & \multicolumn{2}{|c|}{$* * *$} \\
\hline Cultivar (C) & \multicolumn{2}{|c|}{$* *$} \\
\hline $\mathrm{PD}$ & $* * *$ & $* * *$ \\
\hline $\mathrm{PD} \times \mathrm{C}$ & \multicolumn{2}{|c|}{ NS } \\
\hline Year $\times$ PD & \multicolumn{2}{|c|}{$* * *$} \\
\hline Year $\times C$ & \multicolumn{2}{|c|}{ NS } \\
\hline Year $\times \mathrm{PD} \times \mathrm{C}$ & \multicolumn{2}{|c|}{ NS } \\
\hline
\end{tabular}

${ }^{\mathrm{z}}$ Within column and treatment, means followed by the same letter are not significantly different at $P \leq$ 0.05 by Tukey's honestly significant difference. $\mathrm{y}_{\mathrm{NS}}=$ no significant differences detected; $* * * P<$ $0.001,{ }^{*} P<0.01$, and $* P<0.05$.
In Year 1, harvesting began on 30 Oct. 2014 and concluded on 15 Apr. 2015, when plants bolted. In Year 2, harvesting began on 19 Oct. 2015 and ended on 8 Apr. 2016. 'Carmel' was the only cultivar to bolt by the time harvesting was ended in 2016.

Soluble solids content $\left({ }^{\circ}\right.$ Brix). Twenty leaves (five from each replication) were collected from each cultivar in the Cultivar Exp. at harvest for SSC measurements. SSC values were measured for each leaf individually, and thus, 20 SSC values were obtained for each cultivar at each harvest date. Leaves were placed in a plastic bag, sealed, and frozen at $-18{ }^{\circ} \mathrm{C}$. Within 1 week, the leaves were removed from the freezer, allowed to fully thaw to room temperature, and sap was extracted using a manually operated hydraulic press (Year 1) or by squeezing the leaf and petiole between two fingers (Year 2). The extraction method was modified in Year 2 because the hydraulic press required too much time for cleaning between samples for the number of samples that had to be processed. Following extraction, $\approx 1 \mathrm{~mL}$ sap from each leaf was placed on the lens of a handheld refractometer (Milwaukee Instruments, Inc., Rocky Mount, NC) and SSC recorded [method adapted from Ito et al. (2015)].

\section{Temperature}

Air and soil temperature data were logged at 1-h intervals for the duration of both experiments using TMC6-HD thermocouples connected to Hobo U12-008 4-channel outdoor data logger (Onset Computer Corporation, Bourne, MA). Temperature loggers were installed both outside and inside high tunnels. Inside, loggers were placed on the edge of the center row at the same height as plants $(15 \mathrm{~cm})$. Two air temperature sensors

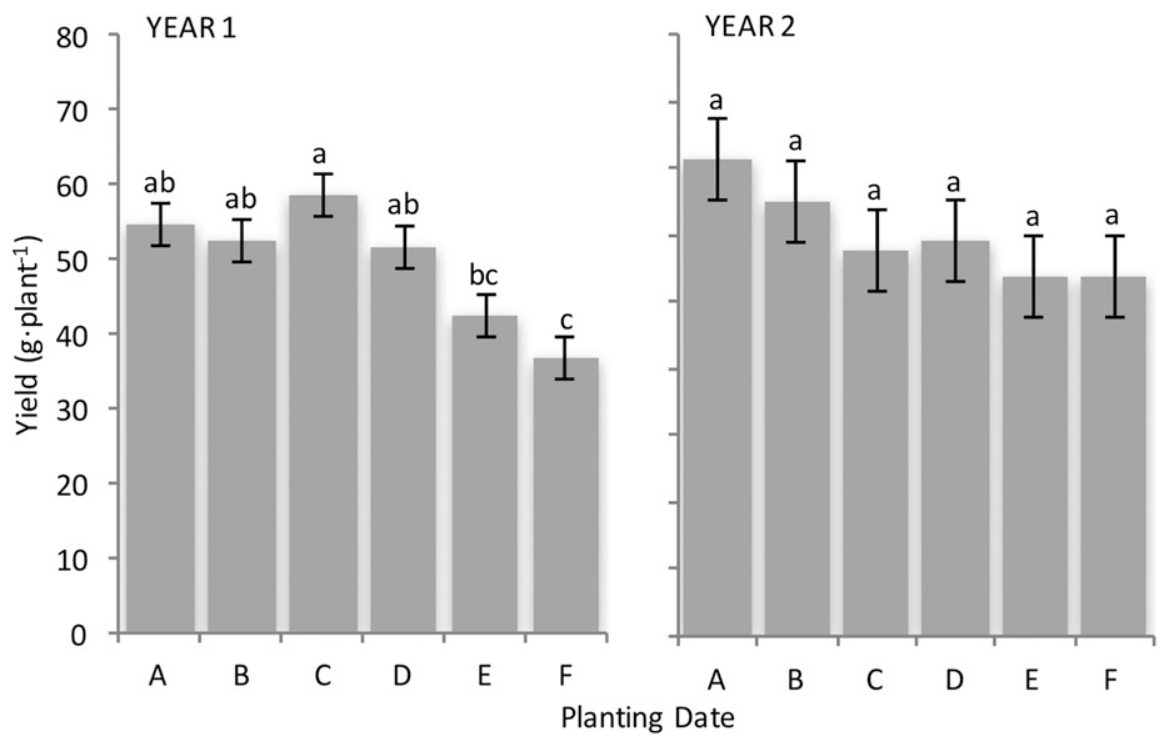

Fig. 4. Total winter-spring (January-April) yield for spinach planted at six fall dates into unheated high tunnels in Durham, NH, in 2014-15 (Year 1) and 2015-16 (Year 2). Letters represent planting date (PD), where $\mathrm{A}=20$ Sept., $\mathrm{B}=30$ Sept., $\mathrm{C}=9$ Oct., $\mathrm{D}=19$ Oct., $\mathrm{E}=30$ Oct., and $\mathrm{F}=9$ Nov. Within year, means with the same letter are not significantly different $(P \leq 0.05$, Tukey's honestly significant difference). Error bars are means \pm one SE $(n=12$, except for PD C, where $n=32)$. were installed at plant height and two soil temperature probes buried $8 \mathrm{~cm}$ beneath the soil surface. Year 1 outdoor air temperatures for October and November are reported by the University of New Hampshire Weather Station because loggers were not yet installed.

\section{Data analysis}

Analysis of variance (ANOVA) was performed to evaluate the effects of year, PD, and cultivar, on total yield, mean SSC, number of days to first harvest, and total number of harvests per PD. For yield and SSC collected at multiple intervals, a repeated measures analysis was conducted. Days to harvest and number of harvests were $\log$ transformed. In the case of a significant interaction among variables, results are presented separately. When an overall $F$ test was significant $(P<0.05)$, treatment means were compared using Tukey's honestly significant difference test at the $P \leq 0.05$ level. For SSC, six common dates between years were used for the repeated measures ANOVA, but all dates were included in determining temperature and SSC correlations. All statistical analyses were performed using JMP Pro 13 (SAS Institute, Cary, NC).

\section{Results}

\section{Environment}

During Year 1, outdoor temperatures were lower than the 30-year average during 5 of 7 months of the experiment (Fig. 1). Conversely, average monthly outdoor temperatures during Year 2 were greater than the 30 -year average in 5 of 7 months. Inside high tunnels, mean air temperatures were greater than outside temperatures in all months of both years. In combination with supplementary rowcover during the coldest months, high tunnels plus rowcover increased mean monthly air temperatures by 2.8 to $8.3^{\circ} \mathrm{C}$ in Year 1 and 3.3 to $5.7^{\circ} \mathrm{C}$ in Year 2, depending on the month.

\section{Planting date experiment}

Days to harvest and number of harvests. Both days to first harvest and number of harvests were affected by PD and year $(P<$ 0.001 ). Days to first harvest ranged from 40 to $130 \mathrm{~d}$ in Year 1 and 19 to $39 \mathrm{~d}$ in Year 2, and were greater in Year 1 for all PDs $(P<$ 0.05 ) (Fig. 2). However, the 2 years were similar in that earlier planting typically resulted in fewer days to first harvest (Fig. 2). Earlier fall planting also resulted in more individual harvests in both years, although we obtained one to three additional harvests for each PD in Year 2 compared with Year 1 (Fig. 3). In Year 1, PD A was harvested 11 times, whereas date $\mathrm{F}$ was harvested only three times. In Year 2, this ranged from 12 to 6 harvests, respectively.

Yield. Year, PD, and cultivar affected total yield $(P<0.001, P<0.001$, and $P<0.01$, respectively), and a year $\times$ PD interaction 
occurred (Table 3). Total yields were $86 \%$ greater in Year 2 than Year 1 (112.7 vs. 60.6 $\mathrm{g}$ /plant, respectively), however; in both years, earlier fall planting resulted in greater total production than late fall planting. Total yield for PDs ranged from 83.8 (A) to $36.8 \mathrm{~g} /$ plant (F) in Year 1, and 165.3 (A) $67.9 \mathrm{~g} /$ plant (F) in Year 2. Planting date A produced greater yields than at least three of five later PDs in both years $(P \leq 0.05)$. Of the three cultivars included in the PD Exp., 'Regiment' produced higher total yields than 'Tyee' (91.8 vs. $81.4 \mathrm{~g} /$ plant, respectively).

To understand the effects of PD on winter through spring production only, total yield was divided into two categories: fall (September-November) and winter-spring (January-April). Significant differences in winter-spring yield among PDs were recorded in Year 1, when PD F produced lower yields during this period than dates $\mathrm{A}$ through D $(P \leq 0.05)$ (Fig. 4). However, most of the PDs were comparable, and in Year 2, there were not differences in yield among PDs $(P \leq 0.05)$ (Fig. 4).

Cultivar experiment. Of the eight cultivars planted on 9 Oct. (C), cultivar did not significantly affect total yield (Table 4). However, yield was strongly influenced by year $(P<0.001)$, and Year 2 yields were greater than Year 1 (122.2 vs. $79.3 \mathrm{~g} /$ plant) (Table 4). Because of a significant year $\times$ month interaction, monthly yield data are presented separately by year (Table 4). In both years, harvest month had a strong effect on production $(P<0.001)$, with April and March producing the greatest yields in Year 1 (38.3 and $15.9 \mathrm{~g} / \mathrm{plant}$, respectively) and March and November in Year 2 (30.4 and $27.7 \mathrm{~g} /$ plant, respectively). October was the lowest yielding month in Year 1, producing essentially no spinach at all, followed by February (1.0 g/plant). In Year 2, January was the lowest yielding month, followed by October (6.9 and $9.3 \mathrm{~g} /$ plant, respectively). The significant cultivar $\times$ month interaction in Year 1 can be attributed to the three highest yielding cultivars in November being among the lowest in April.

Soluble solids content. Within year, a cultivar $\times$ harvest date interaction occurred, and therefore, the average SSC of cultivars is presented individually by harvest date in Fig. 5. Although SSC varied among cultivars by harvest date, it is noteworthy that 'Gazelle' contained among the highest SSC in both years (10.8 and $7.8^{\circ}$ Brix), joined by 'Emperor' and 'Space' in Year 2 (7.8 and 7.4 ${ }^{\circ}$ Brix, respectively) $(P<0.05)$ (Table 5). On the other hand, 'Regiment', 'Tyee', 'Corvair', and 'Renegade' were among the cultivars with the lowest SSC in both years $(P<$ $0.05)$.

SSC was highest during the month of February in both years (Table 5), when monthly average air temperatures inside high tunnels were at their coldest (Year 1) or second to coldest (Year 2). Mean air and soil temperatures for 12-h, 36-h, 7-d, and 10-d intervals before harvest were correlated with the average SSC values of all eight cultivars for each harvest date. The two variables were found to be negatively correlated for all temperature intervals but were most strongly correlated for 10-d average air $\left(R^{2}=0.61, P=\right.$ $0.0073)$ and soil $\left(R^{2}=0.64, P=0.0058\right)$ in Year 1 and 7-d average air $\left(R^{2}=0.78, P=\right.$ $0.0003)$ and soil $\left(R^{2}=0.69, P=0.0014\right)$ temperatures in Year 2 (Fig. 6).

\section{Discussion}

We believe our study is the first to systematically investigate fall-planted spinach in unheated high tunnels in New England for harvest throughout the late fall, winter, and spring months. Our work demonstrates that spinach yield is highly dependent on the growing conditions of a given year, as well as fall PD.

Although the effect of later planting on days to first harvest, number of harvests, and total yield was consistent between years, we observed fewer days to first harvest, increase yield, and an increased number of harvests and yield for each PD in Year 2 compared with Year 1. These findings demonstrate that in addition to fall $\mathrm{PD}$, the conditions of a growing season and the tunnel environment may greatly influence production. Year 1 average temperatures were below the 30 -year norm for the area during 5 of 7 months, whereas in Year 2, they were above the 30 -year average in 5 of 7 months. Because of considerable differences in temperature, we attribute most of the variation in yield between years to vastly different growing conditions. However, it is certainly possible that the preplant fertility regime between years may also have influenced yield or that the structural variation between high tunnels may have affected the microclimate and, therefore, crop growth. However, by nature, high tunnels are not a highly controlled environment, and high tunnels are found in a variety of styles and ages on farms across the region. Because of the combination of these factors, we believe we provide a realistic yield range for fall transplanted spinach in high tunnels in New England. Nevertheless, our results show how challenging it can be for commercial producers to make yield estimates and sales agreements in advance of the winter season.

In Year 1, total yield from the 19 Oct. (D) PD of $51.7 \mathrm{~g} /$ plant is equivalent to minimum yields reported by New York producers in a similar hardiness zone (6B) for directseeded spinach at a comparable fall PD (Blomgren and Frisch, 2007). However, in Year 2, when monthly average temperatures exceeded the 30-year norm, all PDs in our experiment produced considerably higher yields than the prior year. During this time, the 19 Oct. (D) date produced $95 \%$ greater total yields than the previous year, 34\% greater than maximum yield reported by New York State producers (Blomgren and Frisch, 2007). Similarly, Year 1 yield from the 9 Nov. (F) PD was nearly identical to total yields obtained from transplants at a comparable PD and hardiness zone (5b)
Table 4. Effect of year, harvest mo., and cultivar on yield of eight spinach cultivars planted into unheated high tunnels on 9 Oct. (planting date C) during 2014-15 (Year 1) and 2015-16 (Year 2) in Durham, NH.

\begin{tabular}{|c|c|c|}
\hline \multicolumn{3}{|c|}{ Yield (g/plant) } \\
\hline Total & \\
\hline Year 1 & \multicolumn{2}{|c|}{$79.3 b^{z}$} \\
\hline Year 2 & \multicolumn{2}{|c|}{$122.2 \mathrm{a}$} \\
\hline Month & Year 1 & Year \\
\hline October & $0.0 \mathrm{e}$ & $9.3 \mathrm{~cd}$ \\
\hline November & $12.4 \mathrm{c}$ & $27.7 \mathrm{a}$ \\
\hline December & $5.6 \mathrm{~d}$ & $17.2 \mathrm{~b}$ \\
\hline January & $6.1 \mathrm{~d}$ & $6.9 \mathrm{~d}$ \\
\hline February & $1.0 \mathrm{e}$ & $11.1 \mathrm{c}$ \\
\hline March & $15.9 \mathrm{~b}$ & $30.4 \mathrm{a}$ \\
\hline April & $38.3 \mathrm{a}$ & $19.7 \mathrm{~b}$ \\
\hline \multicolumn{3}{|l|}{ Significance $^{\mathrm{y}}$} \\
\hline Year (Y) & \multicolumn{2}{|c|}{$* * *$} \\
\hline $\mathrm{Y} \times \mathrm{M}$ & \multicolumn{2}{|c|}{$* * *$} \\
\hline $\mathrm{Y} \times \mathrm{C}$ & \multicolumn{2}{|c|}{ NS } \\
\hline Cultivar (C) & NS & NS \\
\hline Month (M) & $* * *$ & $* * *$ \\
\hline $\mathrm{C} \times \mathrm{M}$ & $* * *$ & NS \\
\hline
\end{tabular}

${ }^{\mathrm{z}}$ Within column, mean yields sharing letters are not different by Tukey's honestly significant difference test at the $P \leq 0.05$ level.

$\mathrm{y}_{\mathrm{NS}}=$ no significant difference detected, $* * * P<$ $0.001, * * P<0.01$, and $* P<0.05$.

in Utah (37.32 vs. $36.8 \mathrm{~g} /$ plant, respectively) (Ernst et al., 2012). However, in Year 2, yields in our study were $82 \%$ greater than those obtained in Year 1 and by Ernst et al. (2012).

The difference in total yield among fall PDs significantly affected gross revenue potential (Fig. 7). For example, PD A produced an average of $1.03 \mathrm{~kg} \cdot \mathrm{m}^{-2}$ more than $\mathrm{PD} \mathrm{C}$, and up to $2.8 \mathrm{~kg} \cdot \mathrm{m}^{-2}$ more than PD F (Fig. 7). Using these yield differences and a conservative revenue estimate for direct-market winter spinach in the region of $\$ 22.05 / \mathrm{kg}$ (Blomgren and Frisch, 2007; MOFGA, 2015; UVM, 2013), we estimate producers may gain $\$ 22.71$ and $\$ 61.74 / \mathrm{m}^{2}$ by planting 20 Sept. instead of 9 Oct. or 9 Nov., respectively (Fig. 7).

Despite the financial advantages to planting earlier in the fall, high tunnels are an important tool for extending the season of warm-season crops into the fall months in the region (Carey et al., 2009; Fitzgerald and Hutton, 2012; Knewtson et al., 2010; Lamont, 2009), and it is probable that a portion of growers may be less concerned with fall spinach production to continue harvesting already-established summer crops. These growers will likely transition the tunnel later in the fall for winter-spring spinach (January through April) production. In this case, it is still advantageous to plant as early as possible, because total yield (fall + winter-spring) for a planting established on 30 Oct. (E) is likely to be $\$ 5.73 / \mathrm{m}^{2}$ more profitable than one established 9 Nov. (F). However, our results show that winter-spring yield is more similar among fall PDs than total yield (fall + winter-spring), a conclusion also reported by Knewtson (2008) in Kansas. In fact, total yield from January through April did not differ among most PDs in Year 1, or among any of the PDs in Year 2. This indicates that if 

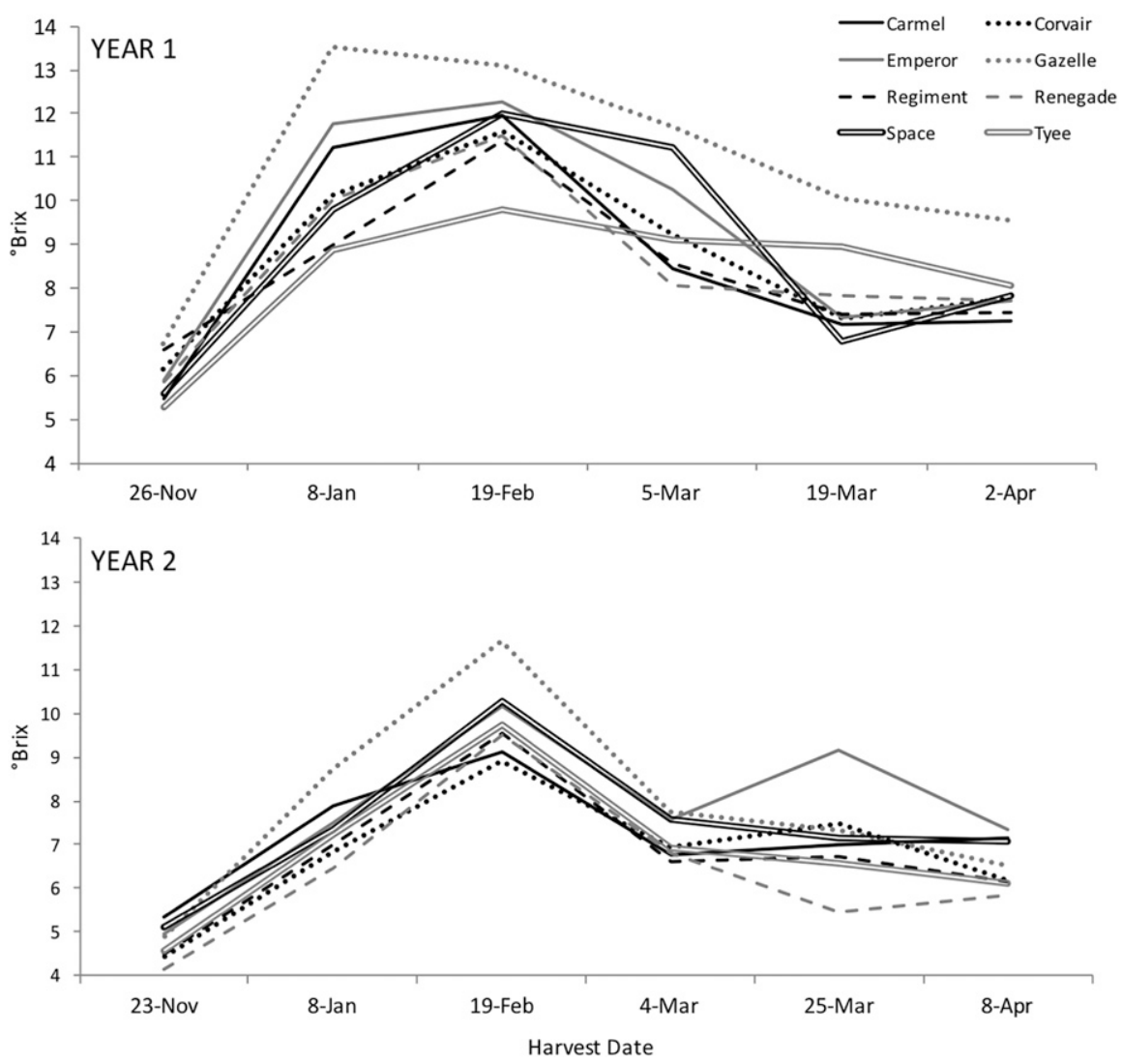

Fig. 5. Soluble solids content ( ${ }^{\circ}$ Brix) of eight spinach cultivars grown in unheated high tunnels in Durham, NH, at six different harvest dates in Year 1 (2014-15) and Year 2 (2015-16). Twenty soluble solids ( ${ }^{\circ}$ Brix) values were obtained for each cultivar at each harvest date $(n=4)$.

Table 5. Harvest date and cultivar effects on leaf and petiole sap soluble solids content (SSC) ( ${ }^{\circ}$ Brix) for eight spinach cultivars grown in unheated high tunnels in Durham, $\mathrm{NH}$, in 2014-15 (Year 1) and 2015-16 (Year 2).

\begin{tabular}{lcc}
\hline & SSC ( ${ }^{\circ}$ Brix) \\
\hline & Yr 1 & Yr 2 \\
\hline Harvest date & & \\
November & $5.9 \mathrm{e}^{\mathrm{z}}$ & $4.7 \mathrm{~d}$ \\
January & $10.5 \mathrm{~b}$ & $7.4 \mathrm{~b}$ \\
February & $11.7 \mathrm{a}$ & $9.9 \mathrm{a}$ \\
March (early) & $9.6 \mathrm{c}$ & $7.1 \mathrm{~b}$ \\
March (late) & $7.9 \mathrm{~d}$ & $7.1 \mathrm{~b}$ \\
April & $7.9 \mathrm{~d}$ & $6.5 \mathrm{c}$ \\
Cultivar & & \\
Regiment & $8.4 \mathrm{~d}$ & $6.8 \mathrm{de}$ \\
Space & $8.9 \mathrm{bc}$ & $7.4 \mathrm{ab}$ \\
Tyee & $8.3 \mathrm{~d}$ & $6.8 \mathrm{~cd}$ \\
Carmel & $8.6 \mathrm{~cd}$ & $7.2 \mathrm{bc}$ \\
Corvair & $8.7 \mathrm{~cd}$ & $6.8 \mathrm{cde}$ \\
Gazelle & $10.8 \mathrm{a}$ & $7.8 \mathrm{a}$ \\
Emperor & $9.2 \mathrm{~b}$ & $7.8 \mathrm{a}$ \\
Renegade & $8.5 \mathrm{~cd}$ & $6.4 \mathrm{e}$ \\
Significance & & \\
Year & & $* * *$ \\
Cultivar (C) & $* * *$ & $* * *$ \\
Date (D) & $* * *$ & $* * *$ \\
C $\times$ D & $* * *$ & $* * *$ \\
\hline
\end{tabular}

${ }^{\mathrm{z}}$ Within column and treatment, means followed by the same letter are not significantly different at $P \leq$ 0.05 by Tukey's honestly significant difference test. $\mathrm{y}_{\mathrm{NS}}=$ no significant difference detected, $* * * P<$ $0.001,{ }^{*} P<0.01$, and $* P<0.05$.

winter and early spring production is the objective, transplanting can occur anytime between 20 Sept. (A) and at least 19 Oct. (D) without compromising yield from January through April.

The lowest yielding months were December, January, and February, although it is notable that we continued to harvest fresh spinach on a regular basis throughout these deep winter months without any supplemental heat or lighting in the high tunnel. This demonstrates that not only can spinach be overwintered in a high tunnel in our location (with supplemental rowcover) but also that it is not necessary to destructively harvest plants during the winter months marketable leaves during winter months in New England.

The effect of cultivar on production was less pronounced than the effects of year or PD, but 'Regiment' was higher yielding than 'Tyee'. We did not observe any differences in yield among the eight cultivars included at PD C (9 Oct.), which suggests that several varieties may be suitable for production in our region during the winter months.

In our experiments, SSC was most strongly negatively correlated with 7-d (Year 2) and 10-d (Year 1) average air and soil temperatures. Negative correlations between temperature and SSC have been shown in other studies (Gent, 2016; Ito et al., 2013, 2015; Proietti et al., 2009; Tamura, 2002), and experiments measuring actual freeze tolerance (i.e., percent of electrolyte leakage because spinach will continue to produce from leaves) suggest that increased sugar content is strongly associated with freezing tolerance in spinach (Guy et al., 1992; Tamura, 2002). Our results are generally consistent with Tamura (2002), who established a negative relationship between 7-d mean minimum air temperature and actual sugar content. In controlled experiments conducted at $10{ }^{\circ} \mathrm{C}$, Proietti et al. (2009) also reported increase in sugar levels after 7-d of plant chilling, and rhizosphere-chilling experiments have demonstrated a sharp increase in SSC at day 6 (Ito et al., 2013). Roots exposed to even colder temperatures $\left(4{ }^{\circ} \mathrm{C}\right)$ have shown increased $\mathrm{SSC}$ in just $4 \mathrm{~d}$ (Ito et al., 2015). While temperatures this low were experienced during winter months in New Hampshire, diurnal fluctuations in temperature prevent us from commenting on the specific effect of temperatures this low on SSC. Still, the strong relationship we observed between SSC and temperature support the connection illustrated by others under controlled experimental conditions, and validates this relationship under realworld production conditions.

It is noteworthy that mean SSC values differed significantly among cultivars, with Gazelle and Emperor containing the highest SSC in both years. If SSC is used as an indicator for freezing tolerance, this may support work showing cultivars vary in their freezing tolerance (Fennell and $\mathrm{Li}$, 1985), even though this did not result in a difference in season-long total yield in our experiments.

While SSC is regarded as a gauge of sugar content in vegetables (Ito et al., 2015), differences of only a few ${ }^{\circ}$ Brix among cultivars may not be noticeable by consumers. In which case, marketing cultivars by name for their SSC may not be the best approach. Instead, because our work shows that SSC nearly doubles from November to mid-February, a better approach may be to promote winter-grown spinach as a sweeter product. Increases in SSC this large are likely to be detectable by consumers, especially when compared with spinach purchased from mild climates during the winter months (i.e., from the grocery store). Because consumers place value on sweetness (Abbott, 1999), spinach purchased from regional producers during this time may be considered of higher quality. This may permit producers to obtain higher prices for their off-season spinach and create a marketing opportunity for spinach produced during cold months in the region.

\section{Conclusion}

We demonstrated that PD and year strongly affect yield of spinach grown in unheated high tunnels from fall through spring. In general, early-fall PDs (midSeptember through early October) maximize fall and cumulative yields, but yield is also subject to annual variations depending 

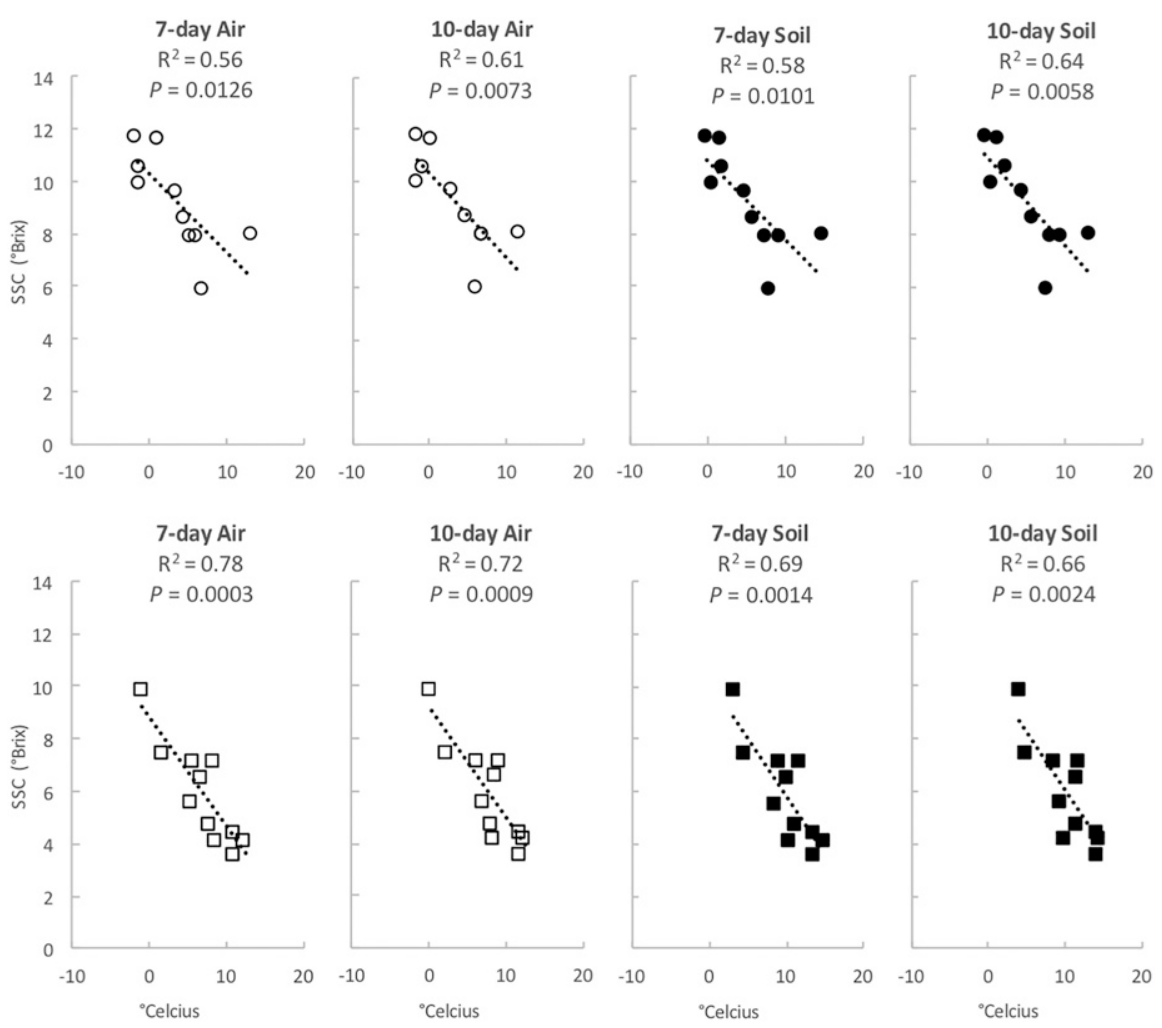

Fig. 6. Correlation between spinach leaf (and petiole) sap soluble solids content (SSC) ( ${ }^{\circ}$ Brix) and 7 and 10-d average air and soil temperatures before harvest from unheated high tunnels in Durham, $\mathrm{NH}$, during 2 years. Year 1 (2014-15) is indicated with circles and Year 2 (2015-16) with squares. Each data point represents one harvest date, and SSC on that date is the average of cultivars Regiment, Space, Tyee, Carmel, Corvair, Gazelle, Emperor, and Renegade, which were transplanted into the high tunnel on 9 Oct. (planting date C).

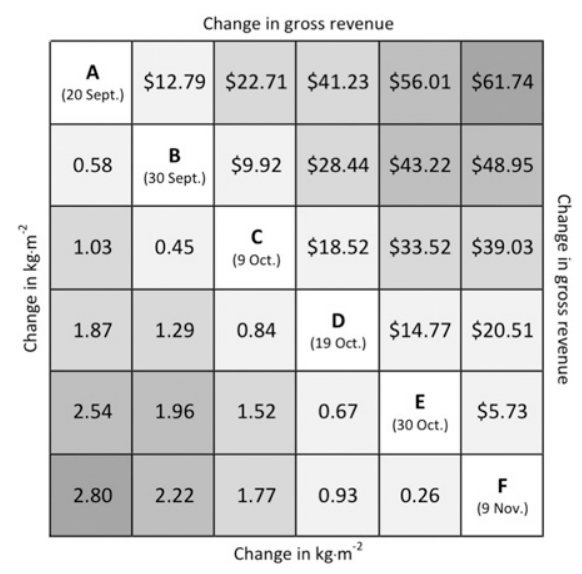

Fig. 7. Yield and gross revenue matrix for spinach transplanted into high tunnels at six fall planting dates (PDs). Below PDs, where two dates connect (the earlier date vertically and the later date horizontally), values represent the increase in total marketable yield for the earlier date compared with the later date. Above PDs, the same intersection shows the potential revenue increase associated with this yield difference. Values are based on local price estimates for winter harvested spinach of $\$ 22.05 / \mathrm{kg}$ (Blomgren and Frisch, 2007; MOFGA, 2015; UVM, 2013) and yield average spinach yield for the $2014-15$ and $2015-16$ seasons in Durham, NH. on weather patterns. In addition, we demonstrated that delayed transplanting of a winter spinach crop until mid-October did not compromise January-April yields. Our results highlight the importance in identifying key production periods and devising a planting plan that takes into account the range of growing conditions and possible yield outcomes. We suggest that it is advantageous to use multiple fall PDs to diffuse the risk of spinach maturing too early or late. Lastly, we propose that because higher leaf SSC content is a unique characteristic of spinach grown under cold temperatures, this may be a marketing opportunity for producers in our region. Further studies investigating the difference in yield between transplanted and direct-seeded spinach, as well as additional cultivars, would be useful.

\section{Literature Cited}

Abbott, J. 1999. Quality measurement of fruits and vegetables. Postharvest Biol. Technol. 15:207225.

Bjelić, V. and Dj. Moravčević. 2006. Effect of prewinter sowing on earliness and yield of spinach. J. Agr. Sci. 51(1):1-6.

Blomgren, T. and T. Frisch. 2007. High tunnels: Using low-cost technology to increase yields, improve quality and extend the season. Univ. Vermont Ctr. Sustainable Agr., Burlington, VT.

Bohnert, H.J. and B. Shen. 1999. Transformation and compatible solutes. Scientia Hort. 78:237-260.
Borrelli, K., R.T. Koenig, and B.M. Jaeckel. 2013. Yield of leafy greens in high tunnel winter production in the northwest United States. HortScience 48:183-188.

Carey, E.E., L. Jett, W.J. Lamont, Jr., T.T. Nennich, M.D. Orzolek, and K.A. Williams. 2009. Horticultural crop production in high tunnels in the United States: A snapshot. HortTechnology 19:37-43.

Dicklow, B. and L. McKeag (eds.). 2016. 20162017 New England vegetable management guide. Univ. Massachusetts Ext., Amherst, MA.

Ernst, T., D. Drost, and B. Black. 2012. High tunnel winter spinach production. Utah State Univ. Coop. Ext.

Fennell, A. and P.H. Li. 1985. Rapid cold acclimation and deacclimation in winter spinach. Acta Hort. 168:179-183. (Hort. Abstr. 10:17660).

Fitzgerald, C.B. and M. Hutton. 2012. Production practices and challenges with high tunnel systems in Maine. J. Natl. Assn. County Agr. Agents 5(2): 1-8.

Gent, M.P.N. 1991. High tunnels extend tomato and pepper production. Connecticut Agr. Expt. Sta. Bul. 893.

Gent, M.P.N. 2016. Effect of irradiance and temperature on composition of spinach. HortScience 51:133-140.

Guy, C.L. and D. Haskell. 1987. Induction of freezing tolerance in spinach is associated with the synthesis of cold acclimation induced proteins. Plant Physiol. 84:872-878.

Guy, C.L., J.L.A. Huber, and S.C. Huber. 1992. Sucrose phosphate synthase and sucrose accumulation at low temperature. Plant Physiol. 100:502-508.

Hunter, B., D. Drost, B. Black, and R. Ward. 2012. Improving growth and productivity of earlyseason high-tunnel tomatoes with targeted temperature additions. HortScience 47:733-740.

Ito, A., H. Shimizu, R. Hiroki, H. Nakashima, J. Miyasaka, and K. Ohdoi. 2013. Effect of different durations of root area chilling on the nutritional quality of spinach. Environ. Control Biol. 51(4):187-191.

Ito, A., H. Shimizu, R. Hiroki, H. Nakashima, J. Miyasaka, and K. Ohdoi. 2015. Qualitative relationship of the nutritional quality of spinach with temperature and duration in root area chilling treatment. Environ. Control Biol. 53(1):35-42.

Knewtson, S., E.E. Carey, and M.B. Kirkham. 2010. Management practices of growers using high tunnels in the central great plains of the United States. HortTechnology 20:639-645.

Knewtson, S.J.B. 2008. Studies in vegetable and high tunnel production on the central great plains. Kansas State Univ., Manhattan, PhD Diss. Proquest Abstr. No. 3320234.

Lamont, W.J., Jr. 2009. Overview of the use of high tunnels worldwide. HortTechnology 19:25-29.

Lamont, W.J., Jr., M.D. Orzolek, E.J. Holcomb, K. Demchak, E. Burkhart, L. White, and B. Dye. 2003. Production system for horticultural crops grown in the Penn State high tunnel. HortTechnology 13:358-362.

Levitt, J. 1980. Responses of plants to environmental stresses: Chilling, freezing, and high temperature stresses. 2nd ed. Academic Press, New York, NY.

Martin, C.A. and R.G. Sideman. 2012. Sprouting broccoli growth in high tunnels for spring harvest in the northeastern United States. HortTechnology 22:345-352.

Martin, E.C. 2009. Methods of measuring for irrigation scheduling: When. Arizona Coop. Ext. Bul. AZ1220. 
McGrath, M.T. 2017. Downy mildew developing in spinach in northeastern U.S. Cornell Univ. Ext. Vegetable MD Online. 1 Feb. 2018. <http:// vegetablemdonline.ppath.cornell.edu/NewsArticles/SpinachDownyMildew.html>.

Maine Organic Farmers and Gardeners Association (MOFGA). 2015. Fall 2015 organic price report.

National Oceanic and Atmospheric Administration (NOAA). 2000. US climate normals: Frost/ Freeze data 1971-2000. 1 Feb. 2018. <https:// www.ncdc.noaa.gov/climatenormals/clim20supp1/ states/NH.pdf>

Nobel, P.S. 1974. Temperature dependence of the permeability of chloroplasts from chillingsensitive and chilling-resistant plants. Planta 115:369-372.
O’Connell, S., C. Rivard, M.M. Peet, C. Harlow, and F. Louws. 2012. High tunnel and field production of organic heirloom tomatoes: Yield, fruit quality, disease, and microclimate. HortScience 47:1283-1290.

Proietti, S., S. Moscatello, F. Famiani, and A. Battistelli. 2009. Increase of ascorbic acid content and nutritional quality in spinach during physiological acclimation to low temperature. Plant Physiol. Biochem. 47:717-723.

Taiz, L. and E. Zeiger. 2002. Plant physiology. 3rd ed. Sinauer Assoc. Sunderland, MA.

Tamura, A. 2002. Changes in the freezing tolerance of spinach (Spinacia oleracea L.) and komatsuna (Brassica campestris L.) from autumn to early spring in an unheated greenhouse. J. Jpn. Soc. Hort. Sci. 71(1):74-81.
U.S. Department of Agriculture (USDA). 2012. USDA plant hardiness zone map. 18 May 2017. $<$ http://planthardiness.ars.usda.gov/ $>$.

U.S. Department of Commerce. 2010. Climatography of the United States 1981-2010. Network, I.D. 272174, Durham, NH. 11 July 2016. $<$ http:/www.ncdc.noaa.gov/cdo-web/datatools/ normals $>$.

University of New Hampshire Weather Station. 2016. Air temperature statistics. 28 Feb. 2017. $<$ http://www.weather.unh.edu/multiple.mp $>$.

University of Vermont (UVM). 2013. Typical prices for vegetable and berry crops in Vermont. Factsheet.

Wien, H.C. and M.P. Pritts. 2009. Use of high tunnels in the northeastern USA: Adaptation to cold climates. Acta Hort. 807:55-60. 